\title{
Universiteit
}

Leiden

The Netherlands

\section{Digitalisering en dynamiek : over de consequenties van de digitale revolutie voor de media-industrie, in het bijzonder de uitgeverij}

Rutten, Paul

\section{Citation}

Rutten, P. (2007). Digitalisering en dynamiek : over de consequenties van de digitale revolutie voor de media-industrie, in het bijzonder de uitgeverij. Leiden University Press. Retrieved from https://hdl.handle.net/1887/27368

Version: $\quad$ Not Applicable (or Unknown)

License: $\quad$ Leiden University Non-exclusive license

Downloaded from: $\quad$ https://hdl.handle.net/1887/27368

Note: To cite this publication please use the final published version (if applicable). 


\section{Digitalisering en dynamiek}

Over de consequenties van de digitale revolutie voor de media-industrie, in het bijzonder de uitgeverij

\section{Paul Rutten}

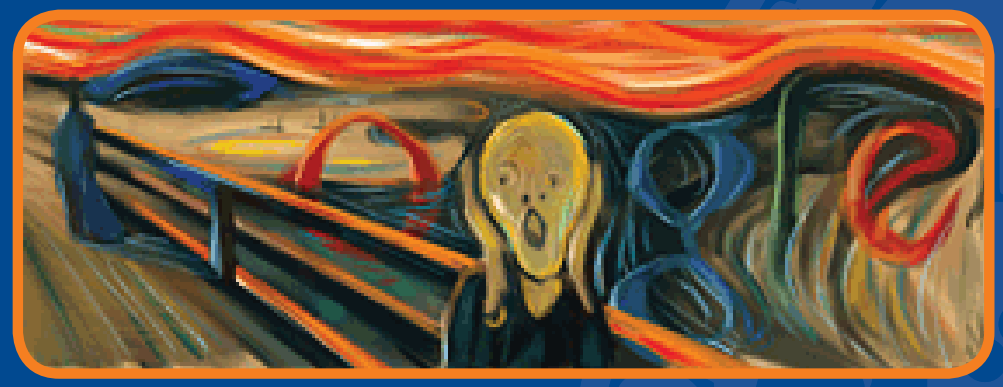

LUP ORATIES 


\section{Digitalisering en dynamiek}





\title{
Digitalisering en dynamiek
}

Over de consequenties van de digitale revolutie voor de media-industrie, in het bijzonder de uitgeverij

\author{
Rede \\ uitgesproken bij de aanvaarding van het ambt van \\ hoogleraar Digitale Mediastudies \\ aan de Universiteit Leiden \\ op vrijdag 29 september 2006 \\ door
}

\section{Paul Rutten}


Omslagontwerp: Randy Lemaire, Utrecht

Zetwerk: JAPES, Amsterdam

ISBN 9789087280154

NUR 615

(C) Leiden University Press, Amsterdam, 2007

Leiden University Press is een imprint van Amsterdam University Press

Alle rechten voorbehouden. Niets uit deze uitgave mag worden verveelvoudigd, opgeslagen in een geautomatiseerd gegevensbestand, of openbaar gemaakt, in enige vorm of op enige wijze, hetzij elektronisch, mechanisch, door fotokopieën, opnamen of enige andere manier, zonder voorafgaande schriftelijke toestemming van de uitgever.

Voorzover het maken van kopieën uit deze uitgave is toegestaan op grond van artikel $16 \mathrm{~B} \mathrm{Au-}$ teurswet $1912 \mathrm{j}^{\circ}$ het Besluit van 20 juni 1974, Stb. 351, zoals gewijzigd bij het Besluit van 23 augustus 1985, Stb. 471 en artikel 17 Auteurswet 1912, dient men de daarvoor wettelijk verschuldigde vergoedingen te voldoen aan de Stichting Reprorecht (Postbus 3051, 2130 KB Hoofddorp). Voor het overnemen van gedeelte(n) uit deze uitgave in bloemlezingen, readers en andere compilatiewerken (artikel 16 Auteurswet 1912) dient men zich tot de uitgever te wenden. 
Mijnheer de Rector Magnificus, zeer gewaardeerde toehoorders, waarde collega's, lieve familie en vrienden,

Wie over digitalisering praat, heeft het over een proces van verandering. De gevolgen van digitale technologie laten zich iedere dag voelen. E-mail is een communicatiemiddel dat inmiddels in de samenleving is ingeburgerd. Chipcards die gegevens bevatten over wie we zijn, wat we bezitten en wat ons daarom is toegestaan, zijn onmisbaar in het dagelijkse verkeer. Via het internet hebben we direct en elektronisch toegang tot een ongekend breed aanbod van informatie. Tekst, videobeelden, animaties en geluid komen in een geïntegreerde informatiestroom tot ons. Digitalisering heeft verschillende nieuwe media opgeleverd. Naast het internet springen computergames letterlijk en figuurlijk het meest in het oog. Ze zijn ontstaan op de digitale golf en maken een ongekende groei door.

Hoewel boeken, kranten en tijdschriften op het eerste gezicht niet veranderd lijken, laat digitalisering zich ook dáár gelden. Zo is het proces van de informatieproductie en -verwerking, voorafgaand aan het drukproces, grondig veranderd. Ook het drukken zélf is door digitalisering beïnvloed. Digitaal drukken biedt nieuwe mogelijkheden. Het wordt mogelijk om kleine oplages tegen aanvaardbare kosten op de markt te brengen. Daardoor kunnen uitgevers eerder tot productie en uitgave van boeken of tijdschriften overgaan. Al met al heeft de omwenteling voor de gedrukte media eerder het karakter van een stille revolutie. De veranderingen voltrekken zich vooralsnog buiten het directe gezichtsveld van de lezers. ${ }^{1}$

De opmars van digitale informatie- en communicatietechnologie heeft niet alleen gevolgen voor het informatieaanbod. Ook de rol van burgers verandert. Nieuwe media zijn vaak interactieve media; burgers kunnen meer dan ooit het verloop van het informatieproces zelf sturen. Ook leveren ze steeds frequenter een bijdrage aan de informatie die via het world wide web wordt aangeboden. Dat gebeurt bijvoorbeeld door een beoordeling van een boek, film, restaurant of vakantieaccomodatie op een daartoe ingerichte website. Andere internetgebruikers kunnen daardoor een beter geïnformeerde keuze maken. Fameus is inmiddels de Wikipedia- 
encyclopedie die door bijdragen van gebruikers zelf, vorm krijgt. Een ander verschijnsel dat sterk de aandacht trekt is weblogging. Een weblog of blog is een website waarop burgers persoonlijke ervaringen en eigen denkbeelden over allerlei zaken kenbaar maken via internet. Blogs zijn in opmars. Iedere seconde komt er ergens in de wereld één bij. Begin 2006 werd het totale aantal geschat op 25 miljoen. Het huidige groeitempo zorgt iedere vijf maanden voor een verdubbeling. ${ }^{2}$ De afzonderlijke blogs bereiken doorgaans slechts een klein publiek. Door het grote aantal en de groei daarin is het echter wel degelijk een verschijnsel van belang. Om de nieuwe rol van burgers in openbare communicatie te benoemen is het predikaat 'prosumer'3 bedacht, een samensmelting van de woorden 'consumer' en 'producer'. Ze consumeren en produceren tegelijkertijd.

De beschikbaarheid en toegankelijkheid van informatie zijn door digitale technologie enorm toegenomen. In die zin is er sprake van een analogie met de komst van de boekdrukkunst. Ook toen was er sprake van een uitdijend aanbod van informatie, echter in een aanmerkelijk lager groeitempo dan op dit moment, dat zult u begrijpen. Net als toen leidt de toename van het aanbod ook nu niet tot verzadiging. Integendeel, de behoefte en afhankelijkheid van informatie lijken met de opmars van digitale media juist verder te groeien. Informatie en kennis zijn meer dan ooit sleutelwoorden geworden, niet alleen in het onderwijs, maar ook in economie en samenleving. Die duiden we respectievelijk aan als kenniseconomie en informatiesamenleving. In de concurrentiestrijd tussen landen en continenten gelden kennis en de toepassing ervan als een sleutel tot succes en wordt de mate waarin burgers geschoold zijn én waarin ze toegang hebben tot digitale hulpmiddelen en informatie, gezien als een belangrijke maatstaf voor concurrentiekracht. Mensen die zich niet kunnen redden in de virtuele wereld worden als probleem gezien; ze bevinden zich aan de verkeerde kant van de digitale kloof.

\section{Digitalisering}

In haar technische essentie is digitalisering een nieuwe manier van ontwikkeling, verwerking, verspreiding en consumptie van informatie. Allerlei verschillende soorten informatie worden tot dezelfde, binaire basisstructuur van nullen en enen teruggebracht. Teksten, afbeeldingen, bewegende beelden, muziek en wat dies meer zij, kunnen bovendien in één informatiestroom worden geïntegreerd. Die stroom wordt langs elektronische weg, bijvoorbeeld via het internet, aan geïnteresseerde burgers aangeboden. De gebruiker kan de afloop van het informatieproces 
zelf bepalen; digitale media zijn interactieve media. Een van de eerste succesvolle toepassingen hiervan was de digitale encyclopedie. Die bevatte naast tekst ook muziek en bewegende beelden, die bovendien op een gemakkelijke manier elektronisch doorzoekbaar waren. Met gemak overtrof de elektronische encyclopedie de functionaliteit van de papieren variant in ruime mate.

Een andere eigenschap van digitale informatie is dat zij niet is vastgeklonken aan specifieke netwerken, informatiedragers of apparatuur. Digitale informatie kan via verschillende netwerken verspreid worden, op allerlei informatiedragers worden opgeslagen en via verschillende soorten randapparatuur worden geconsumeerd. Digitale informatie is daardoor veel beweeglijker dan de oudere analoge. Dat heeft bijvoorbeeld tot gevolg dat het kijken naar televisieprogramma's niet langer louter via het televisietoestel hoeft te gebeuren. Het kan ook via de computer en ook steeds vaker via de mobiele telefoon. Digitale distributie betekent dat de inhoudelijke grenzen tussen verschillende informatienetwerken zijn geslecht. Daarom telefoneren veel mensen nu via de kabel en gebruiken we netwerken die we eerst alleen gebruikten om telefoongesprekken te voeren, nu voor het ontvangen van omroepprogramma's.

Bij dit alles komt nog dat het produceren, toegankelijk maken en op grote schaal verspreiden van digitale informatie niet langer is voorbehouden aan officiele instanties als mediabedrijven of voorlichtingsafdelingen van grote instellingen. Het is voor veel mensen mogelijk digitale informatie zonder veel moeite met talloze andere burgers, langs elektronische weg, te delen. Weblogs zijn daar een mooi voorbeeld van. Een ander, volgens sommigen minder fraai voorbeeld, zijn de peerto-peer netwerken waar fans muziek met elkaar delen op een manier die de auteurswet niet toestaat. Ook is het relatief simpel om digitale informatie te bewerken en dan verder te verspreiden. Dat neemt overigens niet weg dat er technieken zijn ontwikkeld om waardevolle digitale informatie dusdanig te beveiligen dat ze beperkt toegankelijk is en nauwelijks kan worden bewerkt door gebruikers of 'prosumers'. In jargon noemt men dat 'digital rights management'.

\section{Maatschappelijke implicaties}

De technische essentie van digitalisering moge duidelijk zijn, de bredere maatschappelijke implicaties zijn dat veel minder. Dat er sprake is van een sterke vervlechting van maatschappelijke en technologische ontwikkelingen kan worden afgelezen uit de nieuwe betekenissen die met bepaalde woorden uit onze taal worden 
geconstrueerd. 'Aansluiting' en 'verbinding' roepen zowel associaties op met technologische connectie als met maatschappelijke samenhang of integratie. Veel bedrijven spelen daar in hun reclamecampagnes op in. Hun kernboodschap is dat voor het onderhouden van menselijke relaties technische aansluitingen en verbindingen een voorwaarde zijn. Slagzinnen als 'KPN sluit je aan' en 'Nokia, connecting people' impliceren dat technologische aansluiting leidt tot sociaal voordeel. Maatschappelijke aansluiting bereik je door digitale toegang, liefst breedbandig. Aanschaf van een bepaald type telefoon of verbinding via een telecommunicatienetwerk zijn synoniem met maatschappelijke aansluiting. 'Je surf, donc je suis' lijkt het credo van de digitale burger. Zelfs maatschappelijke identiteit wordt gekoppeld aan virtuele status. Sommige, zogenaamde goeroes beweren zelfs dat je niet bestaat wanneer je niet via Google te vinden bent. Deze zoekmachine ontwikkelt zich tot het kompas van de virtuele wereld. Voor de burger die zijn weg zoekt in de informatiezee van het internet lijkt het motto: 'Ik google en kom boven'. Dat geldt overigens niet voor de bedrijven die aan zoekmachinemarketing. Die hanteren veeleer het motto: 'U googled en ik kom boven.'

\section{Communicatie, technologie en samenleving}

De dubbele associaties die bepaalde woorden uit onze taal oproepen, verwijzen naar een vraagstuk dat het verdient beter begrepen te worden: de relatie tussen digitalisering en samenleving.

Dit past binnen een breder wetenschappelijk veld dat de samenhang tussen technologie en maatschappij onderzoekt. De discussies daarbinnen bewegen zich tussen twee uitersten. Aan de ene kant wordt technologie beschouwd als autonome kracht die voor maatschappelijke verandering zorgt. Mensen worden in die benadering gereduceerd tot marionetten, onderworpen aan wetmatigheden waar ze geen noemenswaardige invloed op uit kunnen oefenen. Aan de andere kant luidt de stelling dat de maatschappelijke veranderingen die met technologie tot stand komen, volledig het resultaat zijn van menselijk handelen en door mensenhanden worden vormgegeven. Technologische verandering is dan in feite een sociale dynamiek, maatschappelijke oorzaken liggen in het menselijk handelen zelf. Dat technologie als zodanig tot bepaalde maatschappelijke verandering leidt, wordt nauwelijks gezien. Onderzoek levert geen ondubbelzinnig bewijs voor het ene of het andere uiterste. 
Overigens vertoont technologie in haar verschijningsvorm en consequenties een treffende gelijkenis met de institutie markt. Zowel 'de technologie' als 'de markt' manifesteren zich als een pseudo-autonome kracht die inbedding, sturing en bijsturing nodig heeft. Zowel aan de markt als aan technologie wordt vaak een werking toegedicht die vooral heilzaam is voor mens en maatschappij, soms zelfs kritiekloos. 'Laat de markt haar werk doen', is vaak het credo, alsof ze kan werken zonder menselijke interventie. Toch zal niemand zover gaan te stellen dat de autonome kracht van markt en technologie zo sterk is dat ze niet door menselijk ingrijpen kan worden bezworen of gestuurd. De mate waarin dat wenselijk is, gebeurt en mogelijk is, is de uitkomst van een maatschappelijk proces en een reeks van politieke discussies en afwegingen.

De Engelse historici Asa Briggs en Peter Burke ${ }^{4}$ hebben de maatschappelijke betekenis van technologische ontwikkelingen in het domein van de openbare communicatie in een historisch perspectief geplaatst. Hun onderzoek strekt zich uit van boekdrukkunst tot internet. In lijn met de denkbeelden van wetenschappers als Harold Innis en Marshall McLuhan, zien zij communicatie niet louter in het licht van wat we 'de media' noemen. Zo nemen ze ook de ontwikkeling van het wegen- en spoorwegnet in hun studie van communicatie onder de loep. Voor de introductie van de telecommunicatie werd de snelheid en reikwijdte van communicatie immers bepaald door de kwaliteit van fysieke transportnetwerken.

Met de komst van telecommunicatie nam snelheid en intensiteit van communicatie aanmerkelijk toe. De beweging van materie en informatie werden losgekoppeld. Het was niet langer noodzakelijk om een fysieke informatiedrager, een boek of een brief, te vervoeren om een boodschap over te brengen. Met de komst van de eerste vorm van telecommunicatie, de telegrafie, kon de boodschap over afstand verspreid worden, los van een informatiedrager. Dat was eerder ook al het geval met rooksignalen en vlagvertoon, maar bleef uiteraard in zijn consequenties beperkter dan bij de telegrafie.

Vóór de introductie van de telecommunicatie had de boekdrukkunst zich al laten gelden als een technologische innovatie met vergaande maatschappelijke gevolgen. Zij zorgde ervoor dat geschriften op grote schaal vermenigvuldigd konden worden. Op die wijze verwierven ze een grotere maatschappelijke invloed dan in de eeuwen daarvoor mogelijk was geweest. Zo is de weerklank van de Reformatie ondenkbaar zonder boekdrukkunst. Briggs en Burke noemen de Reformatie het eerste grote ideologische conflict waarin gedrukt materiaal een belangrijke rol speelde. ${ }^{5}$ Naar het schijnt noemde Maarten Luther de nieuwe drukpers ooit 'Gods 
grootste genadegeschenk', al beschouwde hij de kerk toch vooral als 'een huis van de mond en niet van de pen'. 6

De boekdrukkunst heeft zich in de loop van de geschiedenis verder ontwikkeld door steeds nieuwe technologieën te incorporeren, met als recentste toepassing de digitale technologie. Daarmee hebben het gedrukte woord en beeld hun positie kunnen behouden in een medialandschap dat met de komst van nieuwe informatie- en communicatietechnologieën als telecommunicatie, omroep en uiteindelijk internet, uitermate divers en veelvormig is geworden.

De ontwikkeling van de gedrukte media illustreert dat met de komst van nieuwe media de bestaande media niet verdwijnen, maar een nieuwe rol in het veranderende medialandschap voor zich opeisen. Dat is een les die Marshall McLuhan ons eerder al heeft geleerd. De aloude en zeer persistente misvatting dat nieuwe media bestaande media overbodig maken, heeft menig investeerder aan het eind van de vorige en het begin van deze eeuw met aanzienlijke verliezen moeten bekopen. Dat komt omdat we geneigd zijn nieuwe media te begrijpen in termen van de toepassingen die we al kennen van de oude media. Als gevolg daarvan worden de oudere media te snel afgeschreven. Er is sprake van het 'horseless carriage syndrome'; we kunnen de toekomst alleen maar begrijpen in termen van het verleden. Zo is er geen sprake van een lineair proces van vervanging van printmedia door digitale media, vooralsnog groeit de boekproductie gestaag. Dat betekent echter zeker niet dat er geen sprake is van verandering. Zeker wel! Verwacht kan worden dat de nieuwe media en de aloude printmedia zich in een nieuwe, specifieke verhouding tot elkaar zullen gaan ontwikkelen. Dat proces voltrekt zich nu al. Deze co-evolutie dienen we beter te doorgronden, met het oog op haar maatschappelijke, culturele en economische gevolgen, om zo de betekenis van communicatie in de digitale wereld beter te begrijpen.

We zullen daarin moeten afrekenen met het probleem dat mensen technologie in haar consequenties voor de samenleving, niet volkomen kunnen doorgronden. Dat heeft tot gevolg dat ze in feite onmachtig zijn haar toepassing en maatschappelijke invloed op de langere termijn te bepalen. Technologie is weliswaar het resultaat van menselijk denken en handelen en wordt in haar kortetermijntoepassing vooral sociaal geconstrueerd. ${ }^{7}$ Echter, de uiteindelijke maatschappelijke en culturele consequenties van technologische revoluties bevinden zich buiten het blikveld van de mensen die aan de wieg staan van hun uitvinding en ontwikkeling. Het menselijke vermogen om toepassing en consequenties van technologie in de samenleving te bepalen is beperkt; haar consequenties zijn soms moeilijk beheers- 
baar. In die zin zijn mensen technologisch naïef en realiseren zich pas wat de maatschappelijke consequenties van technologie zijn, wanneer deze zich een niet weg te denken rol en betekenis in de samenleving hebben veroverd. Technologische doorbraken sturen de samenleving op weg naar een onbekende bestemming, die zich tijdens de reis openbaart. Technologie wordt in eerste instantie meestal gebruikt om problemen van gisteren of vandaag op te lossen. Dat ze tegelijkertijd ook een nieuwe praktijk en daarmee ook maatschappelijke effecten, een nieuwe cultuur en nieuwe problemen en vraagstukken tot stand brengt, ontgaat ons vaak. Zo loste de automobiel in de vorige eeuw een mobiliteitsprobleem op, maar leidt datzelfde voertuig in het huidige tijdsgewricht tot talrijke verkeersslachtoffers, bedreiging van de kwaliteit van het leefmilieu en fileleed, waarmee het maatschappelijke effect zich keert tegen het oorspronkelijk bedachte nut; we staan stil in plaats van dat we bewegen.

In dit verband is het zeker nuttig om kort de ontstaansgeschiedenis van het internet te memoreren. De technologische doorbraak die ten grondslag ligt aan dit netwerk van netwerken had niet de toepassing op het oog die het uiteindelijk heeft gekregen. De basis van het internet is ontwikkeld in het hart van het Amerikaanse defensieonderzoek. Het doel was een militair communicatienetwerk te ontwikkelen zonder een kwetsbaar fysiek centrum. Door zijn netwerkkarakter, ondersteund door computers op meerdere locaties, zou het nimmer met één nucleaire klap uit te schakelen zijn. De internettechnologie is vanuit het militaire domein via de wetenschappelijke wereld in de samenleving geïntroduceerd en heeft zich ontwikkeld tot een van de belangrijkste drijvende krachten van de digitale revolutie waar we nu onderdeel van zijn en waarvan we de maatschappelijke repercussies proberen te begrijpen. ${ }^{8}$ De analogie met andere uitvindingen in het domein van media en communicatie is treffend. Zo kon Edison nooit bevroeden dat de door hem ontwikkelde fonograaf en de daarvan afgeleide grammofoon vooral in de amusementsindustrie zijn toepassing zou vinden. Hij dacht eerder aan een kantoortoepassing. In die zin kunnen we het idee van een op lange termijn geplande en beheerste ontwikkeling van communicatietechnologie en haar sociale implicaties gerust terzijde leggen, mocht $\mathrm{u}$ dat idee wellicht koesteren.

\section{Digitale Mediastudies}

Dit gezegd hebbend, wil ik een aantal woorden wijden aan taak en invulling van mijn vakgebied en leeropdracht: 'Digitale Mediastudies'. Fundamenteel daarbij is 
de vaststelling dat bewuste communicatie door middel van menselijke taal een bijzonder kenmerk is van de menselijke soort. De geschiedenis leert ons dat veranderingen in maatschappelijke communicatie tot sociale veranderingen leiden. Digitalisering zorgt momenteel voor vergaande veranderingen in communicatie en samenleving. Het is daarom van essentieel belang om dit proces te bestuderen, te doorgronden en vanuit de opgedane kennis het proces mede vorm te geven. De aanleiding daarvoor is wetenschappelijk, maar de implicaties gaan ook breder. Er zijn maatschappelijke, culturele, politieke en economische doelen mee gediend.

Dit is in algemene zin het fundament van digitale mediastudies als wetenschappelijke activiteit. Het belang van studie en onderzoek naar digitale media ligt niet primair in het digitale karakter van de media. Het gaat om het bijzondere belang van digitalisering als technologie die de mediasector verandert en zorgt voor een revolutie in maatschappelijke communicatie. Op termijn zal ze het karakter van de samenleving grondig veranderd hebben.

Het belang van digitale media is dus gelegen in hun veranderingspotentieel en niet per se in het digitale karakter in technische zin. Zoals er nooit sprake was van een leerstoel analoge media, legitimeert ook het digitale karakter van media als zodanig niet de wetenschappelijke aandacht. De crux van een ordinariaat Digitale Mediastudies ligt in de brede waaier van veranderingen die door digitalisering teweeg worden gebracht. Daar moet dan ook het studieobject van de leerstoel Digitale Mediastudies gesitueerd worden. Het gaat om de verandering in de culturele, economische, politieke en maatschappelijke betekenis van informatie en media onder invloed van het proces van digitalisering. De aanleiding voor de leerstoel is daarmee specifiek voor het tijdsgewricht waarin we ons nu bevinden.

\section{Leidse invulling}

Binnen dat brede veld zal ik streven naar een invulling die past bij het kader en karakter van de Leidse Universiteit, meer in het bijzonder haar Letterenfaculteit. Dáár vanuit is ook de internationale masteropleiding Book and Byte vormgegeven die momenteel haar derde jaargang beleeft en waarbinnen deze leerstoel is gesitueerd. Ik zal de drie belangrijkste kenmerken die de wetenschappelijke focus mede bepalen, hier nader aanduiden.

Het eerste kenmerk heeft betrekking op de aandacht voor de geschreven en gedrukte media in de Leidse context. Die vloeit op verschillende manieren voort uit 
de aanwezigheid van belangrijke collecties aan boeken die Leiden, meer in het bijzonder de universiteit en de bibliotheek, rijk is. Zij vormen vanuit verschillende disciplines object van studie en onderwijs. Daaruit volgen verschillende lijnen die relevant zijn voor onderwijs en onderzoek in het vakgebied Digitale Mediastudies. Daarvan zal ik in de nabije toekomst zeker enkele verkennen.

Allereerst betreft het de toekomst van het boek in het digitale tijdperk. Behalve dat dit onderwerp veel partijen bezighoudt, biedt het een uitstekend aanknopingspunt voor onderzoek naar bredere tendensen in maatschappelijke communicatie. Onderzoek naar deze kwestie vertrekt niet vanuit een nostalgisch gevoel en een vrees voor verlies van een traditie. Het gaat eerder over de vraag op welke wijze de rol en betekenis die het boek eeuwenlang heeft gehad, in de digitale toekomst gestalte krijgen. Daarbij is ook de wijze waarop de uitgeverssector als onderdeel van de media-industrie zich ontwikkelt, een belangrijk aandachtspunt.

Een tweede lijn, die voortvloeit uit de hiervoorgenoemde aandacht voor gedrukte en geschreven media heeft betrekking op de betekenis van digitale mediatechnologie voor het vergroten van de toegankelijkheid van historische collecties en cultureel erfgoed. Daarbij gaat het in eerste instantie om collecties van geschreven en gedrukte werken, in tweede instantie echter ook om andersoortig cultureel erfgoed. Een van de markante en verrassende eigenschappen van digitale mediatechnologie is dat ze de samenleving meer, beter en efficiënter dan ooit toegang kan geven tot haar eigen culturele verleden. Het culturele, sociale en zelfs economische potentieel van die ontwikkeling is enorm. De Nederlandse overheid heeft zich hierin gelukkig niet onbetuigd gelaten door aanzienlijke hoeveelheden financiële middelen te verstrekken voor de digitalisering en ontsluiting van een groot deel van de edities van de Nederlandse dagbladen en voor het zeker stellen van een belangrijk deel van het Nederlandse audiovisuele erfgoed. Het zou in de lijn der verwachtingen moeten liggen dat een vergelijkbare inspanning ook op het terrein van historische boekencollecties gedaan wordt.

Hiermee hangt ook de tweede Leidse kenmerk samen: het historische perspectief. Dat vertaalt zich in onderzoek naar ontwikkelingen in maatschappelijke communicatie met aandacht voor parallellen in en verschillen tussen historische periodes van omwenteling in communicatie. Deze aanpak stoelt op de overtuiging dat in de studie van concrete ontwikkelingen in specifieke situaties van verandering de mogelijkheid ligt om de communicatierevolutie waar we momenteel getuige van zijn, beter te begrijpen, of om met de Nederlandse historicus Huizinga te spreken: 'Geschiedenis is het duiden van zin, dien het verleden voor ons heeft'. ${ }^{9}$ Deze benade- 
ring ligt ten grondslag aan de masteropleiding Book and Byte, die hiervoor al even werd gememoreerd.

Het derde Leidse accent in het vakgebied Digitale Mediastudies heeft betrekking op Leiden als stad van wetenschap. Verschillende media, historisch gezien de gedrukte maar recenter ook de digitale, spelen een belangrijke rol in de kennisdeling binnen het domein van wetenschappelijk onderzoek én onderwijs. Juist in het domein van wetenschappelijke communicatie voltrekken zich momenteel veranderingen die verstrekkende gevolgen hebben voor het functioneren van het wetenschappelijke veld én de daarbij betrokken partijen. In het bijzonder zijn dat de wetenschappers, de wetenschappelijke instellingen, de uitgevers en de afnemers in de markt: de wetenschappelijke bibliotheken. In het domein van de wetenschappelijke communicatie spelen kwesties en ontwikkelingen waarvan sommige een bredere maatschappelijke geldigheid bezitten. Daar kom ik hierna nog op terug.

\section{Digitale revolutie en de media-industrie}

Aan de verdere uitwerking van deze aandachtsgebieden in de richting van het onderzoek en onderwijs gaat een nadere analyse van de ontwikkeling van de uitwerking van digitalisering op de media-industrie vooraf. Er is een conceptueel kader nodig waarbinnen onderzoek en onderwijs een plaats moeten krijgen.

Het volgende deel van mijn verhaal wil ik daarom besteden aan een beschouwing over de huidige dynamiek van verandering in de media-industrie onder invloed van de digitale revolutie. De media-industrie vat ik daarbij op als het samenstel van instellingen en bedrijven dat zich primair bezighoudt met de creatie, productie en uitgave van informatie, gericht op consumenten én op zakelijke gebruikers.

\section{Digitale distributie legt bijl aan wortel media-industrie}

Het cruciale element in de digitale revolutie, dat zorgt voor de belangrijkste dynamiek van verandering, is de opkomst van digitale distributie, voornamelijk via het internet. Dit fenomeen legt de bijl aan de wortel van de huidige media-industrie. Die bestaat nu uit een optelsom van verschillende, relatief onafhankelijk van elkaar opererende sectoren. Dat zijn bijvoorbeeld de omroep, de muziekindustrie, de uitgevers van gedrukte media, de film- en video-industrie en recent ook de 
gamesindustrie. Deze bedrijfstakken hebben met elkaar gemeen dat ze producten en diensten aanbieden die 'tussen de oren' geconsumeerd worden; ze doen aan betekenisproductie, ze verschaffen cultuur, informatie, amusement en educatie. In hun exploitatiemodel speelt intellectueel eigendom een centrale rol. Ze produceren en exploiteren auteursrecht en naburige rechten.

De eigenstandige positie van deze bedrijfstakken is gebaseerd op de wijze waarop ze informatie distribueren. Die zorgt voor schotten tussen hun waardeketens. Die schermt de muziekindustrie bijvoorbeeld af van de omroep en van de boekenbranche. Daarmee zij niet gezegd dat deze bedrijfstakken nimmer met elkaar te maken hebben. Zeker wel! Echter de manier waarop ze hun rechten exploiteren is fundamenteel anders. Dat is terug te voeren op de informatiedragers en de distributienetwerken die ze gebruiken. Zo heeft de cd lange tijd de structuur en werking van de muziekindustrie bepaalt. De omroep maakt sinds zijn ontstaan gebruik van elektronische infrastructuren die programma's vanuit een centraal punt op een vaststaand tijdstip in een vaststaand tempo naar kijkers en luisteraars transporteren. De basis van de boekenindustrie is een vijfhonderd jaar oud op Gutenbergs uitvinding gebaseerd systeem van gecentraliseerde productie en distributie van boeken. Zo wordt het althans door de voormalige Amerikaanse uitgever Jason Epstein beschreven. ${ }^{10}$ In dit licht is het niet verbazingwekkend dat de meeste bedrijfstakken binnen de media-industrie vernoemd zijn naar hun distributiemedia: boekenbranche, cd-industrie of omroepbedrijf. De distributievorm bepaalt de bedrijfstak. 'The Medium is the Message', met McLuhan gesproken. ${ }^{11}$

Digitalisering doorbreekt die structuur. De gekende distributiewijzen verliezen aan belang ten gunste van online distributie. Die opmars is onomkeerbaar. Daardoor wordt de basis onder het huidige onderscheid tussen de verschillende segmenten van de media-industrie weggeslagen. De verschillende mediabedrijfstakken zullen zich, in hun migratie naar het web, steeds meer vormen naar de wetten van de digitale omgeving. Digitalisering introduceert een andere structuur en een andere manier van werken. ${ }^{12}$ Uiteindelijk zullen de grenzen tussen de sectoren die door verschillende vormen van distributie zijn getrokken, verdwijnen. Dat betekent dat alle vormen en soorten van informatie uiteindelijk worden teruggebracht tot wat met een lelijk en in sommige oren oneerbiedig woord 'content' genoemd wordt. Er ontstaat een breed digitaal speelveld waarop digitale informatie wordt geëxploiteerd. In verschillende delen van de media-industrie is dit proces al ver gevorderd. De muziekindustrie is hiervan een goed voorbeeld. De bedrijfstak wordt momenteel omgevormd naar een digitaal distributiemodel. In het deel van de uitgeverijsector dat zich bezighoudt met het uitgeven van wetenschappelijke 
tijdschriften, is het online model inmiddels dominant. Daar is, meer dan in de muziekindustrie, een winstgevend exploitatiemodel ontwikkeld. De eerste ervaringen in deze sectoren roepen uiteraard veel vragen en discussie op. Die hebben bijvoorbeeld betrekking op intellectuele eigendomsrechten en de machtsverhoudingen tussen auteurs, uitvoerenden, uitgevers en afnemers. ${ }^{13}$ Ook de mate waarin de digitaal uitgegeven informatie toegankelijk is en tegen welke prijs, is onderwerp van controverse. Ervaringen in deze twee domeinen kunnen een voorbode zijn van wat er in de media-industrie in den brede staat te gebeuren.

Online distributie heeft niet alleen consequenties voor bestaande mediabedrijven, zij verschaft ook een aantal nieuwe spelers de entree tot de media-industrie. Ik doel hier in het bijzonder op de instellingen uit het domein van het culturele erfgoed en de archiefwereld. Zij zetten digitale technologie in om burgers en onderzoekers op een betere en efficiëntere manier toegang te geven tot collecties. Op de golven van de digitalisering hebben ze hun missie verbreed en betreden ze de arena van de digitale media-industrie in een nieuwe hoedanigheid; die van elektronisch uitgever. De erfgoedinstellingen kunnen vanuit een onbeschreven blad hun digitaal profiel opbouwen. Ze zitten op een schat van informatie die, wanneer ze wordt onsloten, in educatief en maatschappelijk opzicht van groot belang is. Niet zelden echter worden deze instellingen geconfronteerd met een rechtenproblematiek die online terbeschikkingstelling bemoeilijkt.

\section{World wide web als los-vast gestructureerd informatienetwerk}

Volgend op de digitale distributie doet zich nog een andere ontwikkeling voor die het bestaande beeld en de structuur van de media-industrie diffuser maakt. Die heeft betrekking op de manier waarop de structuur van de informatie die online beschikbaar is, zich ontvouwd als een min of meer spontaan, inhoudelijk gestructureerd netwerk. Er is sprake van een thematische structurering die organisch tot stand komt door de onderlinge verbindingen (links) die op websites worden aangebracht. Het netwerk is bovendien dynamisch; het ontwikkelt zich voortdurend.

De informatie die we op het world wide web vinden, staat zelden op zichzelf. Iedere site bevat behalve interne verwijzingen, in veel gevallen hyperlinks naar andere sites, naar andere informatiebronnen. Webgebruikers worden naadloos doorgeleid van de ene naar de andere site, op basis van inhoudelijke verwantschap. Die praktijk maakt het world wide web tot een gigantisch los-vast gestructureerd informatienetwerk. De onderlinge verwijzingen en verbindingen zijn soms het resultaat van een commerciële afspraak. In de meeste gevallen liggen inhoudelijke 
motieven aan de basis. In sommige gevallen leidt 'hyperlinken' zelfs tot conflicten, zoals onlangs het geval was tussen Google en een aantal krantenuitgevers, naar aanleiding van de doorverwijzing op de Google Newswebsite naar nieuwsberichten in verschillende dagbladen.

De inhoudelijke verwijzingen waarvan online sprake is, beperken zich al lang niet meer tot tekstuele verwijzingen, het gaat ook om allerlei vormen van beeldmateriaal, van animatie tot audiovisuele informatie. Deze praktijk zorgt ervoor dat ook de bestaande indelingen en categorieën van informatie en informatieproducten zullen vervagen. Het is de vraag of categorieën als 'krant', 'televisieprogramma', 'boek' of 'tijdschriftartikel' nog wel geldige en zinnige aanduidingen zijn voor de vorm waarin informatie zich dan aan ons zal voordoen. Zij lossen mogelijk op in de nieuwe, bijna fluïde structuur van het world wide web.

Door deze twee ontwikkelingen, de ontworteling van de bestaande media-industrie en de organische inhoudelijke structurering van de online informatie, staan de ordening van de informatiemarkt in de bestaande mediabedrijfstakken en het huidige scala van producten en diensten onder druk. De media-industrie staat voor de niet geringe opgave om zich aan deze nieuwe praktijk aan te passen. Door de digitalisering van de distributie én door de nieuwe praktijk van informatieaanbod moet ze zich opnieuw formeren en nieuwe inhoudelijke en zakelijke modellen ontwikkelen. Het gaat daarbij niet alleen om nieuwe uitgeefformules. Het is cruciaal om een visie en een strategie te ontwikkelen op uitgeven in het digitale tijdperk én te zoeken naar een verdienmodel in de nieuwe, vooralsnog diffuse omgeving. Dat dit alleen maar mogelijk is in een netwerkconstructie met andere en andersoortige bedrijven lijkt voor de hand te liggen. Geen bedrijf of andersoortige instelling kan dit geheel zelfstandig realiseren.

Een aantal contouren van de toekomst kunnen, ondanks de grote mate van onzekerheid, uitgetekend worden. Het onderscheid tussen de zakelijke en consumentenmarkt zal overeind blijven. Daarbinnen zullen doelgroepen en daaraan gerelateerde thema's leidend zijn voor de definitie van markten. Deze thematische of doelgroepmarkten zullen bediend worden met een breed scala aan multimediale diensten. Behalve het aanbieden van informatiediensten past daarin ook het scheppen van mogelijkheden voor communicatie voor leden van de doelgroep, op basis van een eigen inhoudelijke inbreng. Consumenten worden immers 'prosumers'. Bovendien reikt de betekenis van internet verder dan een nieuw en simpel distributiekanaal van zenders naar ontvangers. Een van de specifieke successen van het internet, zo is immers gebleken, is de bevordering van communicatie tus- 
sen burgers in verschillende hoedanigheden; in hun professionele bestaan en in hun privéleven.

\section{Wetenschappelijk uitgeven}

Dat een dergelijke ontwikkeling niet naar het domein van de science fiction verwezen hoeft te worden, bewijst de huidige trend in de wijze waarop de toegang tot informatie in wetenschappelijke tijdschriften is georganiseerd. In papieren versies van wetenschappelijke artikelen werden en worden lezers via een uitgekiend systeem van verwijzingen attent gemaakt op de werken waaraan auteurs schatplichtig zijn, bijvoorbeeld door middel van voet- of eindnoten. In de digitale versie worden lezers niet alleen op de hoogte gesteld van de titels, ze kunnen er ook, door middel van hyperlinks, direct toegang toe krijgen. Op die wijze kunnen ze hun eigen weg zoeken in een kennisnetwerk dat digitaal tot hun beschikking staat. Bovendien wordt de inhoud van de wetenschappelijke tijdschriften door de uitgevers op een geavanceerde manier doorzoekbaar gemaakt, wat het gebruiksgemak en de toegankelijkheid van de wetenschappelijke informatie aanzienlijk vergroot.

Een probleem bij deze uitgeefformule is dat vaak alleen maar doorverwezen kan worden naar titels waarover de uitgever die de dienst exploiteert rechten van exploitatie en toegang heeft. Kongsies tussen verschillende uitgevers, waarbij wederzijds toegang tot elkaars materiaal wordt gegund, komen zowel gebruikers als exploitanten ten goede. In dit proces spelen derde partijen soms een rol als organisator en bemiddelaar om op die manier aanbieders en vragers ten dienste te staan. In toenemende mate streven wetenschappelijke uitgevers ernaar om ook primair datamateriaal, waar onderzoekers hun analyses op verrichten, ter beschikking te stellen aan abonnees.

We moeten bij dit voorbeeld in het oog houden dat het hier gaat om een door private ondernemingen vormgegeven en ingericht systeem voor een relatief overzichtelijke institutionele markt, namelijk die van de wetenschappelijke bibliotheken. We kunnen er om die reden geen algemene geldigheid aan toekennen. Toch geeft het aan dat het hiervoor geschetste scenario wel degelijk empirische waarde heeft. Die conclusie wordt ondersteund door een aantal recente ontwikkelingen in een belendend perceel: de wetenschappelijke monografieën. Een wetenschappelijke monografie is een verhandeling over één specifiek onderwerp uit een bepaalde discipline, die doorgaans in de vorm van een boek op de markt wordt gebracht. Allerwegen wordt erkend dat deze tak van uitgeverij in een crisis verkeert. Reden daarvoor is dat de belangrijkste afnemers, de universiteitsbibliotheken, zich door 
tal van omstandigheden gedwongen zien een groter deel van hun budget aan abonnementen op pakketten van online wetenschappelijke tijdschriften te spenderen. De markt voor monografieen heeft hieronder te lijden. In navolging van Oxford University Press hebben nu ook het Duitse wetenschappelijke uitgeefhuis Springer en het Brits-Nederlandse concern Elsevier besloten het model dat gehanteerd wordt voor de uitgave van wetenschappelijke tijdschriften toe te passen op monografieën. Afnemers, in hoofdzaak universiteitsbibliotheken, worden door deze uitgevers in staat gesteld een abonnement af te sluiten voor een specifiek aantal jaarlijks uit te geven monografieën in een aantal vooraf gedefinieerde disciplines. Dat abonnement verschaft digitale toegang tot de inhoud van die monografieën, die op een vergelijkbare manier doorzoekbaar en raadpleegbaar zijn als de wetenschappelijke journals. Daarmee hopen deze uitgevers het negatieve tij te keren. Het is overigens een interessante vraag welke waarde dit model heeft voor de elektronische exploitatie van het 'algemene boek'.

\section{Hardware producenten}

In de context van de veranderingen die ik hier bespreek is het ook van belang te wijzen op de rol die producenten van zogenaamde randapparatuur spelen. Dat zijn technische toepassingen die ons in staat stellen informatie tot ons te nemen. In dat verband wordt het boek ook wel eens, bij wijze van ironie, als leesmachine aangeduid. Digitalisering zorgt ervoor dat we voor de consumptie van één bepaalde soort informatie niet langer aangewezen zijn op één specifiek apparaat. Waar we tot voor kort voor het afspelen van bewegende beelden afhankelijk waren van een videorecorder, zijn er nu vele digitale apparaten die dat kunnen. Er zijn inmiddels ook al verschillende kleine elektronische toepassingen op de markt en nog meer in ontwikkeling die het mogelijk maken e-books onderweg te lezen.

De personal computer is een 'machine' die alle soorten digitale informatie toegankelijk maakt. Het is echter niet het meest gebruikersvriendelijke apparaat. Verschillende fabrikanten solliciteren naar een dominante positie op de markt voor mobiele informatieconsumptie. De Apple iPod heeft goede papieren omdat hij zich in de markt een positie verovert vanuit de muziekdienst iTunes. Veel consumenten beschikken inmiddels over een iPod. Nieuwere versies ontpoppen zich steeds vaker als multimediale spelers die mobiele consumptie van allerlei mogelijke vormen van informatie mogelijk maakt, waaronder e-books. Er gaan geluiden op dat verschillende Amerikaanse uitgevers in contact zijn met Apple om een iPod te ontwikkelen met een lezersvriendelijk display om het apparaat geschikt te ma- 
ken voor het lezen van e-books. Zij zouden bereid zijn daarvoor informatie beschikbaar te stellen. ${ }^{14}$ Daaruit kunnen we in ieder geval de les leren dat producenten van randapparatuur een belangrijke rol kunnen spelen bij het doen slagen van nieuwe formules op de informatiemarkt.

Mijnheer de Rector, geachte toehoorders, ik ben me er terdege van bewust dat dit toekomstbeeld talloze vragen oproept. Een van de cruciale problemen is hoe we de huidige situatie waarin de media-industrie zich bevindt, kunnen verbinden met het toekomstbeeld dat ik hier op basis van een aantal richtinggevende ontwikkelingen heb neergezet. Mijn voorstel is om hier nu niet uitgebreid op in te gaan. Wat ik wel wil doen omvat twee beperktere dingen. Allereerst zal ik kort aangeven op welke wijze we door middel van onderzoek een beter beeld zouden kunnen krijgen van het pad dat de Nederlandse media-industrie, in het bijzonder de uitgeefhuizen daarbinnen, op dit moment bewandelen, in het licht van het door mij geschetste toekomstbeeld. Daarna wil ik kort ingaan op een vraag die bij een aantal mensen ongetwijfeld op de lippen brandt, sommige mensen aan het hart gaat en weer anderen misschien zwaar op de maag ligt: wat is de toekomst van het boek in het digitale tijdperk?

\section{Veldtheorie, veldmigratie en uitgeverij}

Vorig jaar publiceerde de Engelse socioloog John P. Thompson de studie 'Books in the Digital Age'. Hierin doet hij verslag van zijn onderzoek naar de veranderingen in de uitgeverijwereld, in het bijzonder binnen de wetenschappelijke uitgeverij en de uitgeverij van tekstboeken voor het hoger onderwijs. Hij bestudeerde de evolutie in beide velden en de invloed van digitalisering erop. Een veld is op te vatten als een ruimte waarin verschillende actoren en organisaties bepaalde posities ten opzichte van elkaar innemen, met elkaar samenwerken of met elkaar concurreren. Velden kennen specifieke markten, maar ze zijn meer dan alleen maar markten. Het gaat om netwerken en relaties, bedrijfskolommen, concurrentievormen, soorten consumenten, afnemers, maar ook bijvoorbeeld beloningssystemen en prijzen. Het gaat dan niet alleen om uitgeverijen, maar ook om auteurs, een overheid die regels stelt of anderszins ingrijpt, en om distributeurs en detailhandelaren. Een veld is in feite een gestructureerde omgeving waar bedrijven in opereren, opkomen, ondergaan of waarvandaan ze vertrekken. Ieder veld kent zijn eigen dynamiek. 
Het belang van deze benadering is dat ze een handvat biedt om op een gedifferentieerde manier de media-industrie en de uitgeverijsector te onderzoeken. Thompsons suggestie is dat verschillende velden binnen het domein van de uitgeverij een eigen specifieke ontwikkeling kennen, ook in termen van de consequenties van digitalisering. De wereld van wetenschappelijk uitgeven onderscheidt zich wezenlijk van de wereld van het literaire uitgeven. Tezelfdertijd zijn er ook overeenkomsten, bijvoorbeeld doordat in beide velden de vraag speelt wat de toekomst van het boek is in relatie tot het digitale informatieaanbod.

Een goede indicatie voor het bestaan van een veld vormen de institutionele labels die door de uitgeverijsector zelf aan bepaalde onderdelen worden gehangen. De groepsindeling die het Nederlands Uitgevers Verbond hanteert geeft goede indicaties voor de benoeming van velden in de Nederlandse context. Daarin worden bijvoorbeeld aanduidingen als algemene uitgevers en uitgevers voor vak en wetenschap gehanteerd. Daarnaast bestaan er andere groepen, bijvoorbeeld de tijdschriftenuitgevers en de dagbladuitgevers.

De strategieën van uitgeefhuizen kunnen vanuit de veldbenadering nader onderzocht worden. Door na te gaan hoe ze zich in de loop der jaren in één of meerdere velden hebben gemanifesteerd, vanuit welke motieven en met welke gevolgen, onstaat er een duidelijk beeld van hun ontwikkeling. In Thompsons benadering speelt het concept veldmigratie een belangrijke rol. Daarvan is sprake wanneer uitgevers een bepaald veld verlaten en zich in het bijzonder concentreren op een of meerdere andere velden. Dat veldmigratie in de uitgeverijsector een actueel thema vormt, is de afgelopen dagen in meerdere opzichten gebleken. De aankondiging van Wolters Kluwer om de onderwijstak in de verkoop te doen is daar een duidelijk voorbeeld van. In dezelfde week werd, weliswaar in bedekte termen, duidelijk dat de boekenuitgeverij steeds verder af komt te staan van de kernactiviteiten van PCM Uitgevers. Het lijkt een kwestie van tijd voordat Meulenhoff en Bohn Stafleu van Loghum in andere handen overgaan. Opbrengsten kunnen door het concern aangewend worden om de oorlogskas te spekken die nodig is voor de door het bedrijf aangekondigde strijd in krantenland. Iets verder terug liggen de migraties van VNU, weg van de advertentieafhankelijke activiteiten naar de professionele informatievoorziening, en de ontwikkeling van Elsevier, in combinatie met Reed, tot een wetenschappelijk uitgeefhuis. Een analyse van de aard, achtergrond en oorzaken van de migraties van Nederlandse uitgeverijen zou een bijzonder en samenhangend inzicht kunnen geven in de ontwikkeling van een belangrijke sector van onze economie, mediasector en cultuur. Vanzelfsprekend komt de digitalisering daarin als een belangrijke factor aan bod, te midden van andere sig- 
nificante ontwikkelingen. Ik kan hier onder andere wijzen op de schaalvergroting van de uitgeverijsector tot mondiale proporties, gekoppeld aan de vaak gesignaleerde verzakelijking van het uitgeefwezen ten koste van het inhoudelijke engagement van de uitgever. De uitgeverijwereld heeft zich volgens sommigen ontwikkeld van een cottage industry naar een sector waarin het rendementsdenken prevaleert boven cultureel engagement en maatschappelijke missie. Binnen dat kader wordt ook het toenemend belang van investeringsmaatschappijen in strategie en ontwikkeling van uitgeverijen en andere mediabedrijven gezien.

\section{Heeft het boek een toekomst?}

Ten slotte, mijnheer de rector, geachte toehoorders, ontkom ik niet aan enkele bespiegelingen over de toekomst van het boek, een thema dat zich onvermijdelijk opdringt in de context van ordinariaat dat gesitueerd is binnen de masteropleiding Book and Byte.

Het is mijn overtuiging dat het lot van het boek nog lang niet bezegeld is. Op dit moment staat de aarzeling van consumenten om nieuwe hardware c.q. apparaten te omarmen die het mogelijk maken elektronische boeken te lezen de opmars van het e-book in de weg. Anderzijds is de technologische vooruitgang ook op dit terrein niet te stuiten. Daardoor zal er op afzienbare termijn een toepassing komen die ervoor zorgt dat het lezen van e-books meer in zwang raakt. Een dergelijke ontwikkeling zal eerder plaatsvinden wanneer een geaccepteerde leesfunctie onderdeel wordt van een nieuwe generatie van draagbare apparatuur die inmiddels ingeburgerd is, zoals mp3-spelers. Daarmee zal het e-book, door een generatie die met draagbare, elektronische informatieconsumptie is opgegroeid, in belang kunnen groeien. Dat zal zeker kunnen gebeuren wanneer mp3-spelers niet alleen informatie opslaan en weergeven, maar ook draadloos verbinding kunnen maken met het internet en informatie kunnen downloaden.

Daarmee raak ik aan een andere ontwikkeling die de toekomst van het boek zeker zal gaan beïnvloeden en het nu in feite al doet. Het boek als genre en cultureel fenomeen wordt steeds meer onderdeel van de los-vast gestructureerde kennisbank die het world wide web is geworden. Ik heb daar uitgebreid bij stilgestaan. Scanmachines in China en India draaien op dit moment op volle toeren. Van de partijen die momenteel veel werk maken van het scannen van complete boeken is Google de meest in het oog springende partij. De tienduizenden gedigitaliseerde 
files die op basis van de boekscans ontstaan en vindbaar zijn via Google maken boeken onderdeel van het world wide web. In samenwerking met uitgevers scant Google werken waarover de uitgeefhuizen de rechten hebben en maakt ze als titel, via Google Books, vindbaar en maakt de tekst voor een klein deel leesbaar. Google wil met deze investering op de eerste plaats zijn positie als mondiaal leidende zoekmachine verstevigen. Er zijn inmiddels duidelijke aanwijzingen dat dankzij de vindbaarheid op het web via Google bepaalde boeken die gericht zijn op een klein publiek van geïnteresseerden een verkoopimpuls krijgen.

Google gaat echter verder dan de uitgevers. Het bedrijf heeft ook een programma waarin het samen met bibliotheken, waaronder die van de Stanford University, werkt aan het scannen van de gehele collectie, inclusief de titels waarvoor uitgeverijen de rechten hebben, maar die ze niet meer leveren. In jargon heten deze titels 'out of print'. Wie de rechten heeft op digitale terbeschikkingstelling is niet duidelijk, omdat de contracten hierover lang voordat deze vorm van uitgeven in beeld kwam, zijn getekend. Google gaat met deze praktijk de confrontatie aan met de uitgevers die vinden dat het bedrijf daarmee buiten zijn boekje gaat. Overigens toont Google van deze boeken behalve de titel, maar een klein snippertje informatie.

Internetprofeet Kevin Kelly publiceerde in mei van dit jaar onder de titel 'Scan this Book!' een interessant essay in het New York Times Magazine. ${ }^{15}$ Hij stelt dat de tijd voorbij is dat het boek een geïsoleerd informatieobject is. Door de grootschalige scanning van boeken komen werken uiteindelijk in de context van het web terecht waar ze volgens Kelly volledig beschikbaar moeten komen. Door de inhoud te ontsluiten en van trefwoorden te voorzien worden boeken onderdeel van de losvast gestructureerde informatiebank die het world wide web is geworden. Daarmee projecteert Kelly het model dat door wetenschappelijke uitgevers wordt gehanteerd op de grote virtuele bibliotheek die momenteel tot stand komt door de scanningactiviteiten van firma's als het genoemde Google, maar ook door Amazon en Superstar. De laatste is een Chinees bedrijf dat ieder boek uit de 900 universiteitsbibliotheken in Beijng heeft gescand. Het gaat in het totaal om 1,3 miljoen unieke titels in de Chinese taal. Kelly heeft uitgerekend dat van alle 32 miljoen boeken die in de wereld gecatalogiseerd zijn, er zo'n vijftien procent in het publieke domein te vinden zijn. Om ze te gebruiken, online te zetten of anderszins uit te geven is geen toestemming nodig. Voor 75 procent van alle geregistreerde boeken geldt dat ze niet rechtenvrij zijn, maar dat ze 'out of print' zijn. Dat wil zeggen dat ze door de uitgevers niet langer geleverd worden. Je zou kunnen stellen dat ze zich 
in 'het kerkhof van de vergeten boeken' bevinden, een plaats die een centrale rol speelt in de recente bestseller van Carlos Ruiz Zafón ${ }^{16}$ waarvan meer dan 250.000 Nederlandstalige ouderwetse boeken zijn verkocht. Kevin Kelly houdt een vurig pleidooi om alle boeken die op dit kerkhof te vinden zijn, via digitale weg nieuw leven in te blazen. Wanneer dat gebeurt komt een schat aan informatie beschikbaar. Dat zou een gigantische culturele en educatieve aanwinst voor de wereld kunnen betekenen.

Daarmee zij aangegeven dat het leven van boeken als digitaal bestand in de context van het world wide web een empirisch feit is geworden. Tot nu toe is nog niet vaststelbaar op welke wijze deze ontwikkeling de positie van het traditionele boek zal gaan beïnvloeden. Dat zulks gaat gebeuren is echter onontkoombaar. Een van de lessen die de boekenindustrie van de muziekindustrie kan leren is dat het onverwachte partijen kunnen zijn die de doorslag kunnen geven in een innovatietraject. Het zou me niet verbazen wanneer Google Books zich zou ontwikkelen tot de iTunes van de boekenbranche.

Ironisch genoeg hebben ontwikkelingen op het gebied van druktechniek ervoor gezorgd dat boeken die een bestaan leiden als digitale file op het internet of in een meer beschermde omgeving, in de toekomst snel in kleine oplages op verzoek tegen relatief lage kosten in boekvorm gedrukt kunnen worden: printing on demand. Daarmee lijkt de cirkel rond. De eerder genoemde Jason Epstein, sterk pleitbezorger van printing on demand, ziet deze toepassing als een welkom alternatief voor het gecentraliseerde en in zijn ogen achterhaalde systeem van productie en distributie van boeken dat de boekenbranche momenteel nog steeds domineert.

\section{Dankwoord}

Mijnheer de Rector Magnificus, geachte toehoorders.

Ik ben verheugd dat ik hier vandaag mag staan om mijn benoeming als hoogleraar Digitale Mediastudies officieel te aanvaarden.

Er zijn veel mensen en instanties die ik daarvoor dank verschuldigd ben.

Allereerst het College van Bestuur van de Leidse Universiteit en de Faculteit Letteren die in mij het vertrouwen stelt om deze taak in te vullen en uit te voeren. 
Daarnaast ook de mensen die zich ingespannen hebben om de financiering van deze leerstoel rond te krijgen. Het team van Campagne voor Leiden en Herman Spruyt die de fondsen voor dit ordinariaat hebben geworven én uiteraard de bedrijven en instellingen die concreet de middelen voor de eerste vijf jaar hebben toegezegd: VNU, Reed Elsevier, het Leids Universiteitsfonds, Océ-Nederland, Royal Swets and Zeitlinger, Gottmer en het Nederlands Uitgeversverbond.

Ook wil ik mijn directe collega's Berry Dongelmans, Professor Paul Hoftijzer en Professor Adriaan van der Weel danken voor het prettige klimaat van samenwerking dat we hebben opgebouwd sinds februari van dit jaar.

Verder zijn er verschillende mensen die ik wil bedanken voor de bijdrage die ze hebben geleverd aan mijn vorming tot onderzoeker en academicus. Velen zijn hier, wat mij erg vreugdevol stemt. Allereerst mijn voormalige collega's aan de Nijmeegse Universiteit, inmiddels Radboud Universiteit geheten. In het bijzonder wil ik voormalig hoofd van het Instituut voor Massacommunicatie en mijn promotor James Stappers danken. Zijn denkbeelden en opvattingen koester ik nog immer, wat uit de inhoud van mijn rede hier af te lezen is.

Bij TNO heb ik bijna tien jaar gewerkt op het breukvlak van wetenschap en toepassing. Het waren leerzame jaren als sociale wetenschapper in een technologische omgeving. Als 'softe' academicus moest je soms technologen die in hun maag zaten met een oplossing zonder probleem, de weg wijzen. De interacties met wetenschappelijke vogels van verschillende pluimage hebben me veel geleerd. Ik heb daar de eer gehad verschillende mensen te leren kennen die me hebben geïnspireerd, bijvoorbeeld Jos Leyten. Maar ook een aantal oude bekenden uit het Nijmeegse hebben de weg naar TNO gevonden, zoals Valerie Frissen, die hier vandaag ook is en die ik voor haar steun, inspiratie en vaak ook eigengereidheid wil danken. In een aantal van mijn TNO-jaren heb ik kunnen werken als bijzonder hoogleraar Culturele Industrie aan de Erasmus Universiteit. De academische omgeving die ik aantrof was, in combinatie met de meer praktijkgerichte oriëntatie, een perfecte combinatie om theorie en praktijk aan elkaar te toetsen. Dank aan mijn collega's daar die ik nog regelmatig zie bij de begeleiding van aio Miriam van de Kamp, die in Rotterdam aan een proefschrift werkt.

Ook dank aan de collega's bij mijn andere werkkring, de Hogeschool INHOLLAND. Mijn collega-lector daar, Joost Driessen, is een voortdurende bron van in- 
spiratie en uitdaging, die je nodig hebt om scherp te blijven, ook als onderzoeker en wetenschapper.

Ook dank aan mijn familie en schoonfamilie voor hun steun en belangstelling. Dank aan mijn moeder voor wat ze in alle jaren voor mij heeft betekend, samen met mijn vader die helaas in maart van dit jaar is overleden. Hij zou trots geweest zijn.

Ten slotte dank aan jou Hetty, mijn levensgezellin. Jij bent mijn niet-aflatende steun en inspireert mij op vele manieren, niet in de laatste plaats door je artistieke activiteiten die afgezet tegen mijn wetenschappelijke praktijk altijd voor boeiende interacties zorgen. Zonder jouw stimulansen was dit niet gelukt. En lieve zoon Elias. Je hebt ons leven ruim vier jaar geleden op een fantastische manier verrijkt. Je spreekt regelmatig je ambitie uit om professor te worden. Ik wens je veel geluk, maar weet waar je aan begint. Meer dan wie ook bracht je me deze week nog in verlegenheid met de vraag: 'Pappa, wat heb jij eigenlijk uitgevonden?'

Ik heb gezegd. 


\section{Noten}

1. Vgl. John B. Thompson (2005, p. 405-443).

2. It's the Links, stupid. Economist April 20 th 2006

3. Zie onder meer: Hermes en Janssen (2006)

4. Briggs en Burke (2003)

5. Idem, p.73

6. Idem, p.33

7. Zie onder meer: Frissen (2004)

8. Zie voor een verdere uiteenzetting hierover onder andere: Manuel Castells (2003), pp. 21-47.

9. Huizinga (1929, p. 58)

10. Epstein (2001)

11. McLuhan (1994)

12. Vgl. Collis et al. (1997); Rutten en Smeets (1997)

13. Zie bijvoorbeeld: Rutten en van Bockxmeer (2003); Hugenholtz (1999)

14. Apple polishes plans for reader-friendly iPod. Variety 2006

15. Kevin Kelly (2006)

16. Carlos Ruiz Zafón (2004) 



\section{Referenties}

Apple polishes plans for reader-friendly iPod. Variety.com Mon. July 2006 [geraadpleegd op 27 juli 2006].

Briggs, Asa \& Peter Burke (2003). Sociale geschiedenis van de media. Van boekdrukkunst tot internet. Amsterdam: SUN. [Vertaling van: (2002) A social history of the media: from Gutenberg to the Internet. Cambridge: Polity Press].

Castells, Manuel (2003). De melkweg van het internet. Amsterdam: Van Gennep. [Vertaling van: (2003) The internet galaxy. Oxford: Oxford University Press].

Collis, David, J., P. William Bane \& Stephen P. Bradley (1997). Winners and losers. Industry structure in the converging world of telecommunications, computing and entertainment. In: David B. Yoffie (Ed.). Competing in the age of digital convergence. (159-200). Boston, Massachusetts: Harvard Business School Press.

Epstein, Jason (2001), Reading: The Digital Future. In: New York Review of Books, vol. 48 (110), july 5 2001. [http://www/nybooks.com/articles/14318 geraadpleegd 13 september 2006]

Faculteit Letteren (2005). Ordinariaat Digitale Mediastudies: Profielschets. Universiteit Leiden.

Frissen, Valerie (2004). De domestica van de digitale leefwereld. Oratie uitgesproken op 25 januari 2004, Erasmus Universiteit Rotterdam bij de aanvaarding van de leerstoel ICT en Sociale Verandering.

Greco, Albert N. (2005). The book publishing industry. Second edition. London \& Mahwah New Jersey: Lawrence Erlbaum Associates Publishers.

Hermes, Joke en Skylla Janssen (2006). De nieuwe contentmakers. In: Jos de Haan en Christian van 't Hof (red.). Jaarboek ICT en samenleving 2006: De digitale generatie. Amsterdam: Boom Uitgeverij.

Hugenholtz, P.B. (1999). Sleeping with the enemy. Over de verhouding tussen auteurs en exploitanten in het auteursrecht. Oratie, 24 november. Amsterdam: Universiteit van Amsterdam.

Huizinga, Johan (1929). Cultuurhistorische verkenningen. Haarlem: N/V H.D. Tjeenk Willink \& Zoon.

It's the links, stupid. Economist, April 2oth 2006 (geraadpleegd op 18 september 2006)

Kevin Kelly (2006). Scan this Book! New York Times Magazine, 14 mei 2006 [http://www. nytimes.com/2006/05/14/magazine/14publishing.html? ex $=1305259200 \&$ en $=c_{0} 07443 \mathrm{~d}_{3} 68771 \mathrm{bb} 8 \& \mathrm{ei}=5090$ ]

McLuhan, Marshall (1994, oorspr. druk 1964)). Understanding Media. The extensions of man. Boston: MIT Press.

Rutten, Paul en Ingrid Smeets (1987). Entertainmentindustrie. Lijnen naar de toekomst. Apeldoorn: Studiecentrum voor Technologie en Beleid.

Rutten, Paul en Hermineke van Bockxmeer (2003). Cultuurpolitiek, auteursrecht en digitalisering. Delft: TNO Strategie, Technologie en Beleid. 
Thomson, John B. (2005). Books in the digital age. The transformation of academic and higher education publishing in Britain and the United States. Cambridge: Polity Press. Zafón, Carlos Ruiz (2004). De schaduw van de wind. Utrecht: A.W. Bruna Uitgevers. 